\title{
Atmospheric Fate of Monoethanolamine : Enhancing New \\ Particle Formation of Sulfuric Acid as an Important Removal Process
}

\section{Xie, Hong-Bin}

2017-08-01

Xie , H-B , Elm , J , Halonen , R , Myllys , N , Kurten , T , Kulmala , M \& Vehkamäki , H 2017

, ' Atmospheric Fate of Monoethanolamine : Enhancing New Particle Formation of Sulfuric

Acid as an Important Removal Process ' , Environmental Science \& Technology , vol. 51 , no. 15 , pp. 8422-8431 . https://doi.org/10.1021/acs.est.7b02294

http://hdl.handle.net/10138/299835

https://doi.org/10.1021/acs.est.7b02294

acceptedVersion

Downloaded from Helda, University of Helsinki institutional repository.

This is an electronic reprint of the original article.

This reprint may differ from the original in pagination and typographic detail.

Please cite the original version. 


\section{The Atmospheric Fate of Monoethanolamine:}

2 Enhancing New-particle Formation of Sulfuric Acid as

3 an Important Removal Process

4 Hong-Bin Xie ${ }^{\dagger \ddagger}$, Jonas Elm${ }^{\ddagger}$, Roope Halonen*, Nanna Myllys ${ }^{\ddagger}$, Theo Kurtén ${ }^{\S}$, Markku

5 Kulmala ${ }^{\ddagger}$ and Hanna Vehkamäki

$6 \quad$ Key Laboratory of Industrial Ecology and Environmental Engineering (Ministry of

7 Education), School of Environmental Science and Technology, Dalian University of

8 Technology, Dalian 116024, China

9 Department of Physics, University of Helsinki, P. O. Box 64, FIN-00014 Helsinki, 10 Finland

11 Department of Chemistry, University of Helsinki, P. O. Box 55, FIN-00014 Helsinki, 12 Finland

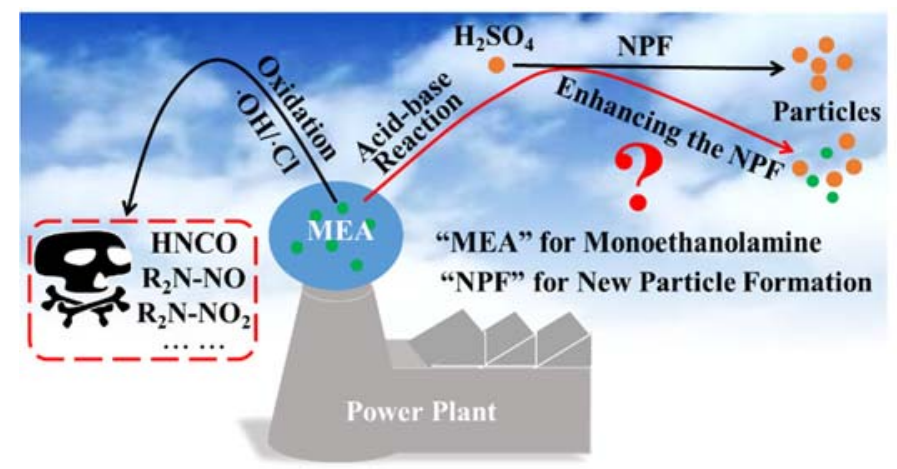

15 ABSTRACT. Monoethanolamine (MEA), a potential atmospheric pollutant from capture unit of a leading $\mathrm{CO}_{2}$ capture technology, could be removed by participating

$17 \mathrm{H}_{2} \mathrm{SO}_{4}$-based new particle formation (NPF) as simple amines. Here we evaluated the 18 enhancing potential of MEA on $\mathrm{H}_{2} \mathrm{SO}_{4}$-based NPF by examining the formation of 19 molecular clusters of MEA and $\mathrm{H}_{2} \mathrm{SO}_{4}$ using a combined quantum chemistry 
calculations and kinetics modeling. The results indicate that MEA at ppt-level can

21 enhance $\mathrm{H}_{2} \mathrm{SO}_{4}$-based NPF. The enhancing potential of MEA is < dimethylamine (DMA), one of the strongest enhancing agents, and 》 methylamine (MA), in contrast to the order suggested solely by their basicity (MEA $<$ MA $<$ DMA). The unexpectedly high enhancing potential is attributed to the role of -OH of MEA in increasing cluster binding free energies by acting as both hydrogen bond donor and acceptor. After the initial formation of one $\mathrm{H}_{2} \mathrm{SO}_{4}$ and one MEA cluster, the cluster growth mainly proceeds by first adding one $\mathrm{H}_{2} \mathrm{SO}_{4}$, and then one MEA, which differs from growth pathways in $\mathrm{H}_{2} \mathrm{SO}_{4}-\mathrm{DMA}$ and $\mathrm{H}_{2} \mathrm{SO}_{4}-\mathrm{MA}$ systems. Importantly, the effective removal rate of MEA due to participation in NPF is comparable to that of oxidation by hydroxyl radicals at $278.15 \mathrm{~K}$, indicating NPF as an important sink for MEA.

\section{INTRODUCTION}

Monoethanolamine (MEA, $\mathrm{NH}_{2} \mathrm{CH}_{2} \mathrm{CH}_{2} \mathrm{OH}$ ) is a benchmark and widely utilized solvent in amine-based postcombustion $\mathrm{CO}_{2}$ capture (PCC) technology. ${ }^{1-9}$ Given the possible large-scale implementation of amine-based PCC, it is likely that there will be relatively significant emissions of MEA or other alkanolamines to the atmosphere from PCC units due to their relatively high vapor pressure. ${ }^{10}$ It has been estimated that a $\mathrm{CO}_{2}$ capture plant which removes 1 million tons $\mathrm{CO}_{2}$ per year from flue gas using MEA as solvent could potentially emit 80 tons MEA into the atmosphere. ${ }^{11,12}$ Therefore, in recent years concern about the atmospheric fate of the representative amine MEA has been increasing, ${ }^{6,13-22}$ as MEA could potentially form an environmental risk. ${ }^{11,12,17}$ 

radical may play a significant role in MEA oxidation at night, though very little is known about this pathway. The reaction rate constants of MEA with $\cdot \mathrm{OH}$ and $\cdot \mathrm{Cl}$ are in the order of $10^{-11}$ and $10^{-10} \mathrm{~cm}^{3}$ molecule ${ }^{-1} \mathrm{~s}^{-1}$, respectively, translating to 2.6-3.6 hours atmospheric lifetime. ${ }^{6,13,14,18,19}$ More importantly, atmospheric oxidation of MEA by $\cdot \mathrm{OH}$ and $\cdot \mathrm{Cl}$ can produce potentially hazardous compounds (such as isocyanic acid, HNCO, nitramine and nitrosamine), ${ }^{6,13,19}$ which can increase the environmental risk of MEA emission. Besides oxidation, acid-base reaction could be another important sink

51 for MEA. However, the atmospheric fate related to the basicity of MEA has received 52 little attention until now.

Atmospheric aerosol particles, at least $50 \%$ of which originates from new-particle

54 formation (NPF), are known to affect human health and remain one of the leading uncertainties in global climate modeling and prediction. ${ }^{23-27}$ Many studies have shown that atmospheric bases such as ammonia and amines stabilize sulfuric acid clusters in the lower troposphere via acid-base reactions, and therefore enhance $\mathrm{H}_{2} \mathrm{SO}_{4}$-based NPF rates. $^{25,28-42}$ Compared to ammonia, amines, including monomethylamine (MA),

59 dimethylamine (DMA) and trimethylamine (TMA), can bind much more strongly to 60 sulfuric acid molecules ${ }^{29,40-43}$ and thus can efficiently enhance clustering sulfuric 61 acid. $^{43}$ Recent work by Almeida et al. performed at the CLOUD chamber at CERN 
shows that $5 \mathrm{ppt}$ of dimethylamine can enhance NPF rates more than 10000 times compared with the case of $5 \mathrm{ppt}$ ammonia, and is sufficient to produce particle formation rates of the same order of magnitude as observed in the atmosphere. ${ }^{25}$ Besides ammonia, MA, DMA and TMA, atmospheric diamines were recently found to efficiently enhance NPF. ${ }^{44,45}$

In a similar fashion to simple alkylamines, MEA can potentially influence NPF via acid-base reactions and therefore participating in NPF could be another atmospheric sink of MEA. A recent study highlighted the possible role of emitted amines from $\mathrm{CO}_{2}$ capture unit of PCC in enhancing NPF. ${ }^{25}$ The basicity of MEA is higher than that of ammonia and lower than that of methylamine and dimethylamine ( $\mathrm{p} K_{\mathrm{b}}$ values of MEA 4.50, MA 3.36, DMA 3.29, ammonia 5.7). ${ }^{46}$ If judged solely by the basicity, MEA should have a higher enhancing effect on $\mathrm{H}_{2} \mathrm{SO}_{4}$-based NPF than $\mathrm{NH}_{3}$, and lower effect than MA and DMA when atmospheric concentration of MEA is assumed to be similar to that of $\mathrm{NH}_{3}, \mathrm{MA}$ and DMA. From the point of molecular structure, MEA has additional -OH compared to ammonia, MA and DMA. When forming clusters between MEA and $\mathrm{H}_{2} \mathrm{SO}_{4}$, the -OH group in MEA can form additional hydrogen bonds $(\mathrm{H}-$ bonds), which increase the binding energy of MEA with $\mathrm{H}_{2} \mathrm{SO}_{4}$. The conflicting effects of one favorable (more H-bonds) and one unfavorable factor (decreased basicity compared with methylamine and dimethylamine) could make it difficult to estimate how strong the enhancing effect of MEA will be. No previous studies have considered the potential role of alkanolamines in NPF involving $\mathrm{H}_{2} \mathrm{SO}_{4}$. An additional - $\mathrm{OH}$ in the 
amine may lead to a different NPF pathway and rate compared to the ammonia/MA/DMA- $\mathrm{H}_{2} \mathrm{SO}_{4}$ systems. Therefore, to obtain a complete view of the atmospheric fate of MEA and extend the current knowledge of NPF involving amines and $\mathrm{H}_{2} \mathrm{SO}_{4}$, information about the potential of MEA to participate in atmospheric NPF is crucial.

In this study, we investigate the initial step of atmospheric $\mathrm{H}_{2} \mathrm{SO}_{4}$-based NPF by examining the formation of molecular clusters of MEA and sulfuric acid using a combination of quantum chemistry calculations and kinetics modeling employing the

91 Atmospheric Cluster Dynamics Code $^{47,48}$ (ACDC). Via systematic conformational searches, we have obtained minimum free energy structures of clusters of composition (MEA)m(SA)n $\left(m=0-4\right.$ and $n=1-4$, "SA" represents $\left.\mathrm{H}_{2} \mathrm{SO}_{4}\right)$. The corresponding thermodynamic data and previously reported results for pure sulfuric acid (SA)1-4 clusters $^{49}$ are used in ACDC to obtain cluster formation pathways and kinetics in the MEA- $\mathrm{H}_{2} \mathrm{SO}_{4}$ system. In addition, the effect of hydration on the cluster formation kinetics of MEA and $\mathrm{H}_{2} \mathrm{SO}_{4}$ is considered.

\section{COMPUTATIONAL DETAILS}

Electronic Structure Calculations. The most critical parameters in identifying cluster

100 formation pathways and kinetics are the cluster formation free energies. Both minimum

101 free energy structures of clusters $(\mathrm{MEA})_{m}(\mathrm{SA})_{n}(m=0-4$ and $n=0-4)$ and computational

102 method will determine the reliability of calculated cluster formation free energies. Here,

103 a global minimum sampling technique (Figure 1), which has previously been applied 
104 to study atmospheric cluster formation, ${ }^{45,50,51}$ was used to search for the global minima

105 of clusters (MEA $)_{m}(\mathrm{SA})_{n}(m=1-4$ and $n=0-4)$. The pure (SA) $1-4$ clusters were taken from

106 the work of Ortega et al. ${ }^{49}$ In Figure 1, all optimizations, frequency or single point

107 energy calculations with density functional theory and semiempirical PM6 level have

108 been performed in GAUSSIAN 09..$^{52}$ The $\omega$ B97X-D functional was selected as the core

109 optimization and frequency calculation method in Figure 1, since it has shown good

110 performance for studying the formation of atmospheric molecular clusters. ${ }^{53,54}$ Single

111 point energy calculations at DLPNO-CCSD(T) (Domain-based local pair natural orbital

112 coupled cluster ${ }^{55,56}$ )/aug-cc-pVTZ level have been performed in ORCA version 3.0.3. ${ }^{57}$

113 Recent studies indicated that the DLPNO-CCSD(T) method can be used to calculate

114 atmospheric acid-base clusters up to 10 molecules $^{58}$ and the utilized DLPNO-

$115 \mathrm{CCSD}(\mathrm{T}) /$ aug-cc-pVTZ method has been shown to yield a mean absolute error of 0.3

$116 \mathrm{kcal} / \mathrm{mol}$ compared to $\operatorname{CCSD}(\mathrm{T})$ complete basis set estimates, based on a test set of 11

117 small atmospheric cluster reactions ${ }^{54}$. The MEA monomer has 13 conformations $^{6,59}$ and

118 each was used as a starting point for forming the molecular clusters. For the global

119 minimum search, more than 10000 randomly oriented configurations were built for

120 each cluster. We have estimated the Gibbs free energies for all obtained global minima

121 at $298.15 \mathrm{~K}$ by combining the single point energies at the DLPNO-CCSD(T)/aug-cc-

122 pVTZ level and Gibbs free energy correction terms at the $\omega B$ 97X-D/6-31++G(d,p)

123 level. The formation free energies for each cluster were obtained by subtracting Gibbs

124 free energy of the constituent molecules from that of the cluster at $298.15 \mathrm{~K}$. The 
125 formation free energies at other temperatures were calculated under the assumption that

126 enthalpy and entropy change remain constant in the tropospheric temperature range.

127

128 Figure 1. Flowchart for the multistep global minimum sampling method. "SP"

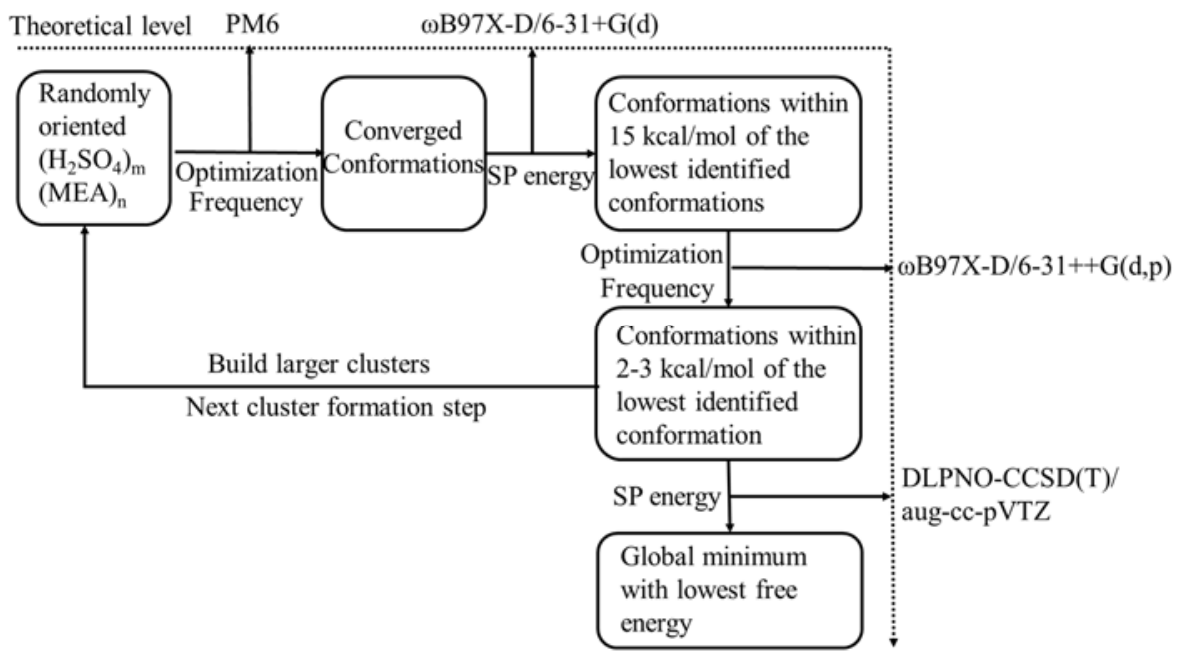

129 represents a single point energy calculation.

130 To consider the effect of hydration, the (MEA) $)_{m}(\mathrm{SA})_{n} \mathrm{~W}_{x}(m=0-2, n=0-2, x=1-3$,

131 "W" represents $\mathrm{H}_{2} \mathrm{O}$ ) clusters were investigated. For their global minimum search, a

132 similar scheme as for the clusters without water molecules was used. In addition, to

133 directly compare the enhancing effect of MEA to ammonia, MA and DMA, we re-

134 evaluated their formation free energies at the same theoretical level, based on reported

135 cluster structures, or new lower energy structures (presented in Figure S1). ${ }^{48,49,60}$ It

136 should be noted that for global minimum of the unhydrated MA-SA clusters, only

137 (MA) $)_{0-3}(\mathrm{SA})_{0-3}$ is available ${ }^{41,60}$ and therefore formation free energy data for MA are

138 only for $(\mathrm{MA})_{0-3}(\mathrm{SA})_{0-3}$

139 ACDC model. We used ACDC to study the formation pathways, steady-state 140 concentrations and formation rates of clusters. The detailed theory behind the ACDC 
141 was present in a study by McGrath et. al. ${ }^{47}$ Briefly, the code generates equations for the

142 time derivatives of the concentrations of all studied clusters, and uses the Matlab ode15s

143 routine to solve differential equations and simulate the time-dependent cluster

144 concentrations. The differential equations, also called birth-death equations, include

145 source terms from collisions of smaller clusters and evaporations from larger clusters,

146 and sink terms from collisions with other clusters and evaporations into smaller clusters.

147 In addition, the cluster formation rate in ACDC is defined as the flux of clusters outside

148 the system. Whether a cluster is allowed to be outside the system or not is judged by

149 the boundary condition. The hydration effect was considered in ACDC by taking $\mathrm{H}_{2} \mathrm{O}$

150 molecule as an environment to affect the collision or evaporation of base-acid cluster. ${ }^{61}$

151 The simulated system is a " $4 \times 4$ box" for unhydrated system, where 4 is the maximum

152 number of $\mathrm{H}_{2} \mathrm{SO}_{4}$ or MEA molecules in the clusters. The (MEA) $4(\mathrm{SA})_{5}$ and

153 (MEA $)_{5}(\mathrm{SA})_{5}$ were allowed to grow out of the system and all other clusters crossing the

154 box edge are brought back to the simulation box by monomer evaporations (see

155 boundary condition in Supporting Information (SI)). The ACDC simulations were

156 primarily run at $278.15 \mathrm{~K}$, with additional runs performed at $258.15,268.15,288.15$

157 and 298.15 to study the temperature effect. A constant coagulation sink coefficient of

$1582.6 \times 10^{-3} \mathrm{~s}^{-1}$ was used as sink term. This value corresponds to typical one observed in

159 boreal forest environments. ${ }^{48}$ The sulfuric acid concentration was set to be $10^{5}, 10^{6}, 10^{7}$,

$16010^{8}$ and $10^{9} \mathrm{~cm}^{-3}$, a range relevant to atmospheric NPF. ${ }^{25,48,62}$ Atmospheric MEA

161 concentrations were set to be 1,10 , and $100 \mathrm{ppt}$, a range relevant to atmospheric NPF 
162 for DMA. ${ }^{25}$ It should be mentioned that the acid concentration $\left[\mathrm{H}_{2} \mathrm{SO}_{4}\right]$ was defined as

163 the total concentration of all neutral clusters containing one acid and any number of

164 base molecules, as in a previous study. ${ }^{48}$ When hydration effect was considered, the

165 simulated system is " $2 \times 2$ box". Average collision and evaporation coefficients over

166 the hydrate distribution for each cluster of $(\mathrm{MEA})_{m}(\mathrm{SA})_{n}(m=0-2, n=0-2)$ were used in

167 the birth-death equations for $\left[\mathrm{H}_{2} \mathrm{SO}_{4}\right]=10^{6}$ and $[\mathrm{MEA}]=10 \mathrm{ppt}$ and at $278.15 \mathrm{~K}$. The

168 equilibrium hydrate distribution for each cluster was calculated by the equilibrium

169 constant for the formation of the respective hydrate. ${ }^{61}$ Similar to the definition of

170 boundary condition of unhydrated MEA-SA cluster, the $(\mathrm{MEA})_{2}(\mathrm{SA})_{3}$ and

171 (MEA $)_{3}(\mathrm{SA})_{3}$ were allowed to grow out of the system. As a comparison, we also

172 preformed ACDC simulation for $\mathrm{MA}-\mathrm{H}_{2} \mathrm{SO}_{4}$ and $\mathrm{DMA}-\mathrm{H}_{2} \mathrm{SO}_{4}$ systems at $278.15 \mathrm{~K}$.

173 The simulated system is a " $3 \times 3$ box" for MA since only (MA) $)_{0-3}(\mathrm{SA})_{0-3}$ is available,

174 and " $4 \times 4$ box," for DMA. The $(\mathrm{MA})_{3}(\mathrm{SA})_{4}$ and $(\mathrm{MA})_{4}(\mathrm{SA})_{4}$, and $(\mathrm{DMA})_{4}(\mathrm{SA})_{5}$ and

175 (DMA) $5(\mathrm{SA})_{5}$ were allowed to grow out of the simulation box for $\mathrm{MA}-\mathrm{H}_{2} \mathrm{SO}_{4}$ and

176 DMA-H2 $\mathrm{SO}_{4}$ system (see SI), respectively. Other ACDC simulation details are similar

177 to those for MEA. In addition, ACDC simulation was performed for $\mathrm{MEA}-\mathrm{H}_{2} \mathrm{SO}_{4}$ with

$1783 \times 3$ box, to compare with $\mathrm{MA}-\mathrm{H}_{2} \mathrm{SO}_{4}$ system with a similar simulation box size.

179 RESULTS AND DISCUSSION

180 Structures and Thermodynamic Data. We use (MEA) $m(\mathrm{SA})_{n}$ to represent the cluster

181 formed by $m$ MEA molecules and $n \mathrm{H}_{2} \mathrm{SO}_{4}$ molecules to avoid explicitly specifying the

182 proton transfer status. Since previous studies have discussed the structures of pure 
183

184

185

$\mathrm{H}_{2} \mathrm{SO}_{4}$ clusters, ${ }^{49}$ here, we mainly focus on the clusters (MEA) $)_{m}(\mathrm{SA})_{n}(m=1-4$ and $n=0$ 4). The structures of $(\mathrm{MEA})_{m}(\mathrm{SA})_{n}(m=1-4$ and $n=0-4)$ are shown in Figure 2. Generally, in the homo-molecular clusters $(\mathrm{MEA})_{m}(m=1-4)$, no proton transfer has occurred and clusters are stabilized mainly by H-bonds. In all hetero-molecular clusters, proton transfer is observed, and clusters are stabilized by both H-bonds and electrostatic interaction between positive and negative species. When $n \geq m$, the amine $\left(-\mathrm{NH}_{2}\right)$ groups of all MEA molecules are protonated by $\mathrm{H}_{2} \mathrm{SO}_{4}$. In this case $\mathrm{H}_{2} \mathrm{SO}_{4}$ only transfers a single proton and in no cases a sulphate ion is formed. When $n<m$, there are two different proton transfer pattern. For (MEA)2(SA), (MEA) $3(\mathrm{SA})$ clusters, none or one of the protons of $\mathrm{H}_{2} \mathrm{SO}_{4}$ are donated, and therefore not all MEA molecules are protonated. For $(\mathrm{MEA})_{4}(\mathrm{SA}),(\mathrm{MEA})_{4}(\mathrm{SA})_{2},(\mathrm{MEA})_{4}(\mathrm{SA})_{3}$ and $(\mathrm{MEA})_{3}(\mathrm{SA})_{2}, \mathrm{H}_{2} \mathrm{SO}_{4}$ can donate two protons, and therefore all MEAs are protonated in the case of $m-n=1$ $\left((\mathrm{MEA})_{4}(\mathrm{SA})_{3}\right.$ and $\left.(\mathrm{MEA})_{3}(\mathrm{SA})_{2}\right)$, while MEA is not completely protonated in the case of $m-n>1\left((\mathrm{MEA})_{4}(\mathrm{SA})\right.$ and $\left.(\mathrm{MEA})_{4}(\mathrm{SA})_{2}\right)$. The above proton transfer patterns for $\mathrm{H}_{2} \mathrm{SO}_{4}-\mathrm{MEA}$ clusters are similar to those of $\mathrm{H}_{2} \mathrm{SO}_{4}$-DMA clusters. ${ }^{48,49}$

Another structural feature in all clusters except $(\mathrm{MEA})(\mathrm{SA})_{3}$ is that $-\mathrm{OH}$ groups of all MEAs can form at least one $\mathrm{H}$-bond with $\mathrm{H}_{2} \mathrm{SO}_{4}$ as $\mathrm{H}$-bond donors. In many cases such as $(\mathrm{MEA})_{3},(\mathrm{MEA})_{4},(\mathrm{MEA})(\mathrm{SA})_{4},(\mathrm{MEA})_{2}(\mathrm{SA})_{3},(\mathrm{MEA})_{2}(\mathrm{SA})_{4}$ $(\mathrm{MEA})_{3}(\mathrm{SA})_{1}, \quad(\mathrm{MEA})_{3}(\mathrm{SA})_{2}, \quad(\mathrm{MEA})_{3}(\mathrm{SA})_{4}, \quad(\mathrm{MEA})_{3}(\mathrm{SA})_{2}, \quad(\mathrm{MEA})_{4}(\mathrm{SA})_{2} \quad$ and (MEA $)_{4}(\mathrm{SA})_{3}$ clusters, the $-\mathrm{OH}$ group of MEA can form another H-bond with the $-\mathrm{OH}$ group of $\mathrm{H}_{2} \mathrm{SO}_{4}$, ammonium cation $\left(-\mathrm{RNH}_{3}{ }^{+}\right)$of protonated MEA or -OH of MEA as a 
205 a spherical three-dimensional structure, especially for the large studied cluster sizes. As 206 an exception (MEA)(SA)3, we also located a low-energy minimum (Figure S2)

207 involving H-bonds where -OH group of MEA acts as both a hydrogen bond donor and 208 acceptor. However, the configuration is not the global minimum for the Gibbs free 209 energy. The binding energy of this minimum is about $1 \mathrm{kcal} / \mathrm{mol}$ lower than that of the 210 free energy global minimum shown in Figure 2, and thus unfavorable entropy effects 211 are taking place in this configuration.
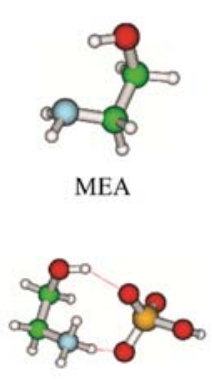

(MEA)(SA)

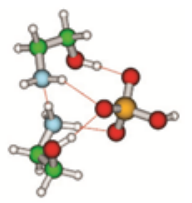

$(\mathrm{MEA})_{2}(\mathrm{SA})$

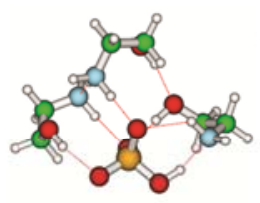

$(\mathrm{MEA})_{3}(\mathrm{SA})$

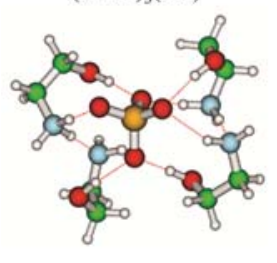

$(\mathrm{MEA})_{4}(\mathrm{SA})$

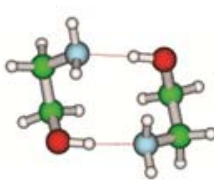

$(\mathrm{MEA})_{2}$

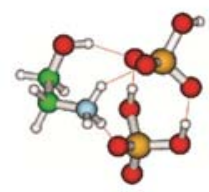

(MEA)(SA)

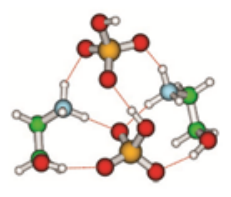

$(\mathrm{MEA})_{2}(\mathrm{SA})_{2}$

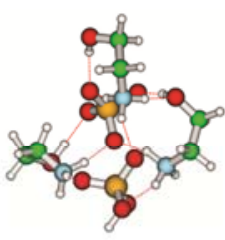

$(\mathrm{MEA})_{3}(\mathrm{SA})_{2}$

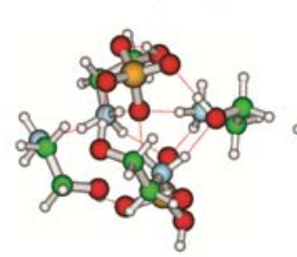

$(\mathrm{MEA})_{4}(\mathrm{SA})_{2}$

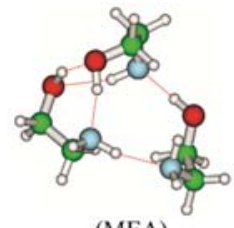

(MEA)

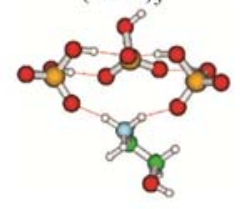

$(\mathrm{MEA})(\mathrm{SA})_{3}$

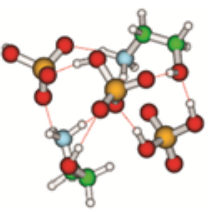

$(\mathrm{MEA})_{2}(\mathrm{SA})_{3}$

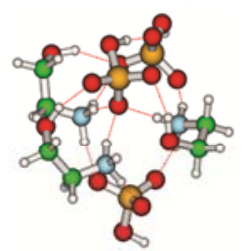

$(\mathrm{MEA})_{3}(\mathrm{SA})_{3}$

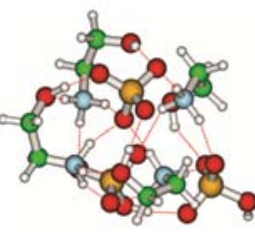

$(\mathrm{MEA})_{4}(\mathrm{SA})_{3}$

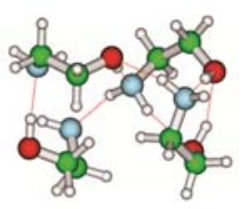

$(\mathrm{MEA})_{4}$

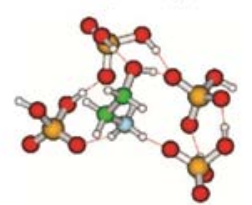

(MEA)(SA)

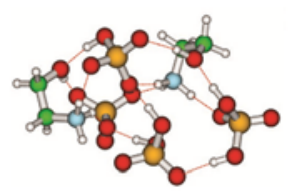

$(\mathrm{MEA})_{2}(\mathrm{SA})_{4}$

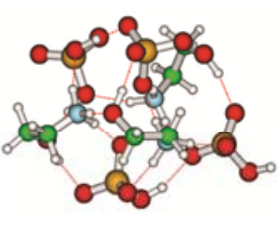

$(\mathrm{MEA})_{3}(\mathrm{SA})_{4}$

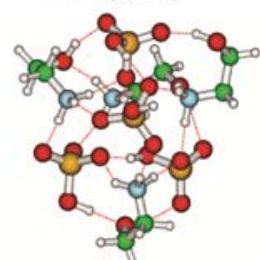

$(\mathrm{MEA})_{4}(\mathrm{SA})_{4}$ 
$214 n=0-4)$ at the $\omega \mathrm{B} 97 \mathrm{X}-\mathrm{D} / 6-31++\mathrm{G}(\mathrm{d}, \mathrm{p})$ level of theory. The red ball represents oxygen

215 atom, blue is nitrogen atom, green is carbon atom and white is hydrogen atom.

216 It is known that DMA is one of the strongest agents for enhancing atmospheric

$217 \mathrm{H}_{2} \mathrm{SO}_{4}$-based NPF. ${ }^{25,29,43}$ Here, we take formation free energies of the $\mathrm{H}_{2} \mathrm{SO}_{4}-\mathrm{DMA}$

218 system as a reference to discuss the formation free energies of $\mathrm{H}_{2} \mathrm{SO}_{4}-\mathrm{MEA}$. The free

219 energy data at $298.15 \mathrm{~K}$ for the formation of the clusters from their constituent

220 molecules for the MEA/DMA- $\mathrm{H}_{2} \mathrm{SO}_{4}$ system are presented in Figure 3, and the

221 corresponding thermodynamical quantities $\Delta H$ and $\Delta S$ are presented in Table S1. For

222 the pure base clusters, formation free energy of all MEA clusters is lower than that of

223 corresponding DMA clusters. This results from the fact that there is one more H-bond

224 bonding agent (-OH) in MEA compared with DMA, which leads to more H-bonds in

225 the pure MEA clusters than that in the corresponding DMA clusters. The formation free

226 energy for most hetero-molecular $\mathrm{H}_{2} \mathrm{SO}_{4}-\mathrm{MEA}$ clusters is $0.2-5.6 \mathrm{kcal} / \mathrm{mol}$ higher than

227 that of corresponding $\mathrm{H}_{2} \mathrm{SO}_{4}$-DMA clusters. However, the formation free energy for $228(\mathrm{MEA})_{2} \mathrm{SA},(\mathrm{MEA})_{3} \mathrm{SA}$ and $(\mathrm{MEA})_{4} \mathrm{SA}$ and $(\mathrm{MEA})_{4}(\mathrm{SA})_{4}$ is lower than that of the 229 corresponding clusters from DMA. The difference in formation free energies of MEA 230 clusters, compared with DMA clusters, originates from the competition between the 231 unfavorable (lower basicity of MEA than that of DMA) and favorable factor (the 232 formation of more H-bonds from the $-\mathrm{OH}$ group of MEA) for forming clusters. In 233 addition, we noted that formation free energies of $\mathrm{MEA}-\mathrm{H}_{2} \mathrm{SO}_{4}$ clusters are lower than 234 those of the corresponding $\mathrm{MA}-\mathrm{H}_{2} \mathrm{SO}_{4}$ clusters (Figure S3) although basicity of MEA 
235 is much lower than that of MA, indicating that the -OH group in MEA does indeed play

236 an important role in the cluster formation between MEA and $\mathrm{H}_{2} \mathrm{SO}_{4}$. In recent study,

237 Chen et al. revealed that besides the basicity, the hydrogen-bonding capacity of $-\mathrm{NH}_{x}$

$238(x=1-3)$ group in amine/ammonia can play an important role in enhancing

239 methanesulfonic acid driven NPF. ${ }^{63}$ Our findings and Chen et al.'s study ${ }^{63}$ together

240 show the importance of molecular interactions involving $-\mathrm{NH}_{x}(x=1-3)$ group and other

241 functional groups of amines in NPF. In addition, similar to MA and DMA, the

242 formation free energies for MEA are much lower than those of $\mathrm{NH}_{3}$ (Figure S3) with

$243 \mathrm{H}_{2} \mathrm{SO}_{4}$.
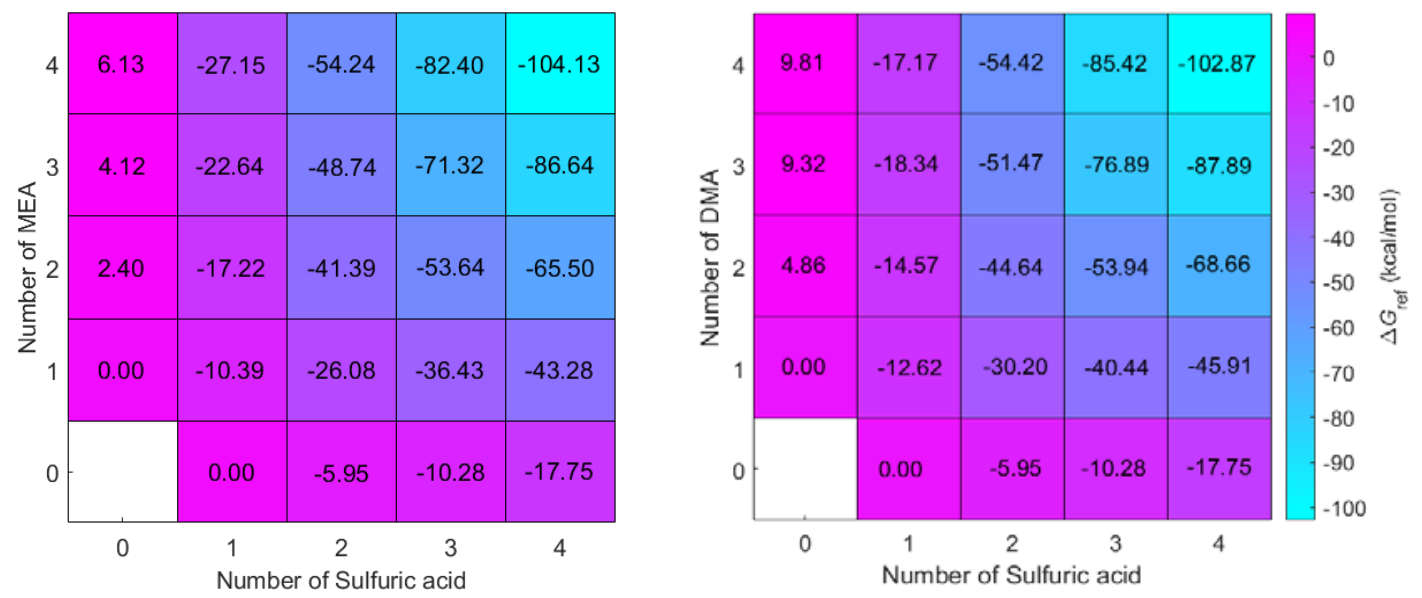

244 Figure 3. Calculated formation free energies for $(\mathrm{MEA})_{m}(\mathrm{SA})_{n}$ (left panel) and 245 (DMA) $m(\text { SA })_{n}$ (right panel) clusters $(m=0-4$ and $n=0-4)$ at the DLPNO-CCSD(T)/aug-

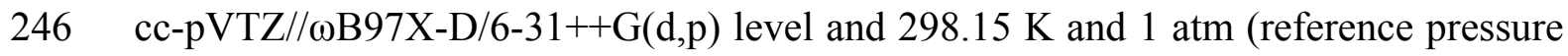
247 of acid and base).

248 Evaporation Rates. In view of the acid-base cluster growth, the stability of the cluster

249 can be deduced by comparing the evaporation rate with the collision rate, which mainly

250 depends on the collision rate constant and the concentration of the acid and base 
251 molecules. However, the collision rate constants for the studied clusters are very close

252 to each other and thus difference in the evaporation rate can be used to represent the 253 stability of clusters at the given acid and base concentration. The evaporation rates for $254(\mathrm{MEA})_{m}(\mathrm{SA})_{n}(m=0-4$ and $n=0-4)$ on the MEA-SA grid at 278.15 are presented in Figure 255 4. Generally, evaporation rates for clusters (MEA) $2(\mathrm{SA})_{2},(\mathrm{MEA})_{1}(\mathrm{SA})_{2},(\mathrm{MEA})_{3}(\mathrm{SA})_{3}$, $256(\mathrm{MEA})_{3}(\mathrm{SA})_{4}$ and $(\mathrm{MEA})_{4}(\mathrm{SA})_{4}$ are of the order of $10^{-3}-10^{-5} \mathrm{~s}^{-1}$, which is much lower 257 than those for other studied cluster sizes. When the concentration of $\mathrm{MEA}$ or $\mathrm{H}_{2} \mathrm{SO}_{4}$ is 258 around or above ppt level, those clusters with evaporation rate $10^{-3}-10^{-5} \mathrm{~s}^{-1}$ can be 259 considered to be stable and $(\mathrm{MEA})_{3}(\mathrm{SA})_{3}$ and $(\mathrm{MEA})_{4}(\mathrm{SA})_{4}$ are the most stable clusters 260 (see discussion on stability of clusters in SI). By checking all evaporation pathways 261 (see Table S2), evaporation of $\mathrm{H}_{2} \mathrm{SO}_{4}$ or MEA monomer is found to be the main decay 262 route for all clusters studied here. If $m$ and $n$ are unequal, evaporation of species with 263 greater number of molecules is always preferred. For clusters with $m=n>2$, 264 evaporation of MEA is faster than that of $\mathrm{H}_{2} \mathrm{SO}_{4}$. In addition, when there is equal 265 number of molecules in two clusters, the evaporation rate of MEA abundant cluster is 266 higher than corresponding $\mathrm{H}_{2} \mathrm{SO}_{4}$ abundant cluster, indicating that the bonding ability 267 of $\mathrm{H}_{2} \mathrm{SO}_{4}$ to the cluster is stronger than that of MEA. A similar phenomena concerning 268 the stronger bonding ability of acid is also found in other acid-base cluster systems, 269 such as DMA-SA, $\mathrm{NH}_{3}-\mathrm{H}_{2} \mathrm{SO}_{4}$, and $\mathrm{NH}_{3}-\mathrm{HNO}_{3} .{ }^{49,64}$ 
271 Figure 4. The evaporation rates for $(\mathrm{MEA}) m(\mathrm{SA})_{n}(m=0-4$ and $n=0-4)$ on the MEA-SA 272 grid at 278.15 .

It is also interesting to compare cluster evaporate rates for the different amines

274 (MA, DMA and MEA) at the same simulation condition. For most of the clusters,

275 including hetero-molecular and pure base clusters, the evaporation rates for MEA

276 clusters are lower than corresponding ones for MA (Figure S4) and DMA (Figure S4)

277 clusters. However, it is not straightforward to conclude which amine can form the most

278 stable clusters as evaporation rates for a couple of clusters with MA and DMA are lower

279 than those of MEA clusters. If the initially formed one SA and one base cluster (which 280 are crucial for cluster growth at relevant $\mathrm{H}_{2} \mathrm{SO}_{4}$ and base concentration for MEA, MA 281 and DMA as discussed in the Growth Pathways section) are compared, evaporate rate 282 of (MEA)(SA) is lower than that of (MA)(SA) and higher than that of (DMA)(SA).

283 Therefore, the stability of initially formed clusters for the three types of amine- $\mathrm{H}_{2} \mathrm{SO}_{4}$ 284 clusters follows the trend $(\mathrm{DMA})(\mathrm{SA})>(\mathrm{MEA})(\mathrm{SA})>(\mathrm{MA})(\mathrm{SA})$ at the given acid and 285 base concentrations. In addition, in accordance with a previous study, ${ }^{47}$ the evaporation 286 of small clusters is found to be the main decay route for some of DMA- $\mathrm{H}_{2} \mathrm{SO}_{4}$ clusters. 
This is not the case for MEA-SA and MA-SA clusters, where monomer evaporation is dominant. This results from the higher stability of the small DMA- $\mathrm{H}_{2} \mathrm{SO}_{4}$ clusters.

Steady-state Cluster Concentrations and Formation Rates. The steady-state sulfuric acid dimer concentration (all clusters including sulfuric acid dimer) and the formation

291 rate of clusters growing out of the simulation box can be taken as two important

292 quantities characterizing the stabilization potential of a given base in $\mathrm{H}_{2} \mathrm{SO}_{4}$-based

293 NPF. ${ }^{25,43,60}$ Figure 5 shows the steady-state sulfuric acid dimer concentration and the

294 cluster formation rate as a function of monomer concentration $\left(\mathrm{H}_{2} \mathrm{SO}_{4}\right.$ concentration in

295 the range $10^{5}-10^{9} \mathrm{~cm}^{-3}$, MEA mixing ratios of $1-100 \mathrm{ppt}$ ) at $278.15 \mathrm{~K}$ for $\mathrm{MEA}-\mathrm{H}_{2} \mathrm{SO}_{4}$

296 clusters, along with DMA- $\mathrm{H}_{2} \mathrm{SO}_{4}$ and $\mathrm{MA}-\mathrm{H}_{2} \mathrm{SO}_{4}$ clusters as a comparison. Generally,

297 the sulfuric acid dimer concentration and the cluster formation rate increase with 298 increasing the concentrations of MEA and $\mathrm{H}_{2} \mathrm{SO}_{4}$ at the considered condition. The 299 MEA concentration dependence of the sulfuric acid dimer concentration and the cluster 300 formation rate weakens with increasing $\mathrm{H}_{2} \mathrm{SO}_{4}$ concentration, indicating that the system 301 gradually approaches saturation with respect to MEA at a high $\mathrm{H}_{2} \mathrm{SO}_{4}$ concentration.

302 Similar behavior is also found in the simulations with MA and DMA as base. More 303 importantly, MEA yields roughly $10-10^{2}$-fold dimer concentration and $10^{2}-10^{3}$-fold 304 formation rate compared to the simulations with MA as a base, and 0.02-0.2-fold dimer 305 concentration and 0.02-1-fold formation rate as compared to the simulations with DMA 306 as a base, indicating the order of the stabilization potential of these three amines 307 follows: DMA $>$ MEA $>$ MA. It deserves mentioning that $\mathrm{MEA}-\mathrm{H}_{2} \mathrm{SO}_{4}$ formation rates 
309 for MEA and MA $(3 \times 3)$ (formation rate of MEA- $\mathrm{H}_{2} \mathrm{SO}_{4}$ will increase 1.1-6 times,

310 compared with $4 \times 4$ box). However, the difference in sulfuric acid dimer concentration

311 was similar with different simulation box sizes. As experimental evidence has shown

312 that DMA and MA have an enhancing effect on $\mathrm{H}_{2} \mathrm{SO}_{4}$-based NPF at ppt level, ${ }^{25,43}$ it

313 can be expected that MEA will have a similar effect with magnitude in between DMA

314 and MA. Therefore, we can conclude that MEA can enhance NPF of $\mathrm{H}_{2} \mathrm{SO}_{4}$ when the

315 atmospheric concentration of MEA reaches ppt level. The higher stabilization potential

316 of MEA, compared with MA, further verifies the important role of the -OH group of

317 MEA in enhancing NPF involving $\mathrm{H}_{2} \mathrm{SO}_{4}$, as the basicity of MEA is lower than that of

318 MA. In addition, both the sulfuric acid dimer concentration and the formation rate

319 present negative temperature dependence in the range of $260-300 \mathrm{~K}$, relevant to

320 tropospheric conditions as shown in Figure S5. The negative temperature dependence

321 effect is more prominent at lower MEA (1 ppt) and lower $\mathrm{H}_{2} \mathrm{SO}_{4}$ concentrations $\left(10^{6}\right.$ $\left.322 \mathrm{~cm}^{-3}\right)$.
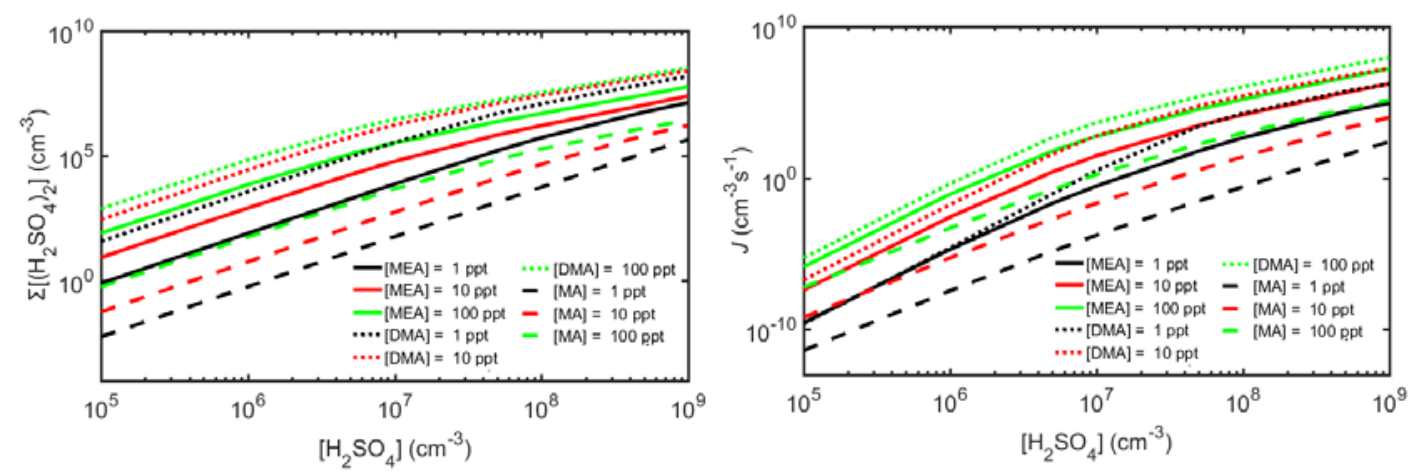

324 Figure 5. Simulated steady-state $\mathrm{H}_{2} \mathrm{SO}_{4}$ dimer concentration $\Sigma\left[\left(\mathrm{H}_{2} \mathrm{SO}_{4}\right)_{2}\right]\left(\mathrm{cm}^{-3}\right)$ (left panel) and the cluster formation rate $J\left(\mathrm{~cm}^{-3} \mathrm{~s}^{-1}\right)$ out of the simulation system (right 
panel) as a function of monomer concentration at $278.15 \mathrm{~K}$.

327 Growth Pathways. Figure 6 presents the growth pathway and the actual Gibbs free energy surface ${ }^{47}$ for MEA and $\mathrm{H}_{2} \mathrm{SO}_{4}$ clusters at $\left[\mathrm{H}_{2} \mathrm{SO}_{4}\right]=10^{6} \mathrm{~cm}^{-3}$, $[\mathrm{MEA}]=10 \mathrm{ppt}$

329 and $278.15 \mathrm{~K}$. The actual Gibbs free energy surface was obtained by converting the 330 change of free energy from 1 atm to the actual vapor pressures of the components. ${ }^{47}$ As 331 can be seen in Figure 6 (left panel), the first step in the growth is the binding of one $332 \mathrm{H}_{2} \mathrm{SO}_{4}$ molecule to a MEA molecule. After the initial step, the growth mainly proceeds 333 by firstly adding one $\mathrm{H}_{2} \mathrm{SO}_{4}$, and then one MEA. The main flux out of the system is the 334 (MEA)4(SA)5 cluster. Combining the growth pathway with the actual Gibbs free energy 335 surface (right panel in Figure 6), two features can be observed. First, clusters do not 336 follow the lowest free energy pathways $\left((\mathrm{MEA})_{1}(\mathrm{SA})_{1} \rightarrow(\mathrm{MEA})_{2}(\mathrm{SA})_{2} \rightarrow(\mathrm{MEA})_{3}(\mathrm{SA})_{3}\right.$ $\left.337 \rightarrow(\mathrm{MEA})_{4}(\mathrm{SA})_{4}\right)$, which would involve the cluster collision with (MEA) $1(\mathrm{SA})_{1}$ cluster. 338 This results from fact that the concentration of the (MEA) $)_{1}(\mathrm{SA})_{1}$ cluster $\left(5.73 \times 10^{3} \mathrm{~cm}^{-}\right.$ $\left.339{ }^{3}\right)$ is much lower than that of the $\mathrm{H}_{2} \mathrm{SO}_{4}$ monomer $\left(9.94 \times 10^{5} \mathrm{~cm}^{-3}\right)$. Secondly, the 340 addition of $\mathrm{H}_{2} \mathrm{SO}_{4}$ monomers involves a small free energy barrier, but the addition of 341 MEA does not. Furthermore, combining the growth pathway with the evaporation rate 342 of the clusters, we can conclude that the formation of initial cluster (MEA $)_{1}(\mathrm{SA})_{1}$ is the 343 rate-determining step for the cluster growth since the (MEA) $)_{1}(\mathrm{SA})_{1}$ cluster is much 344 more unstable than other clusters in the cluster growth pathway and readily evaporates 345 back into MEA and SA monomers. 

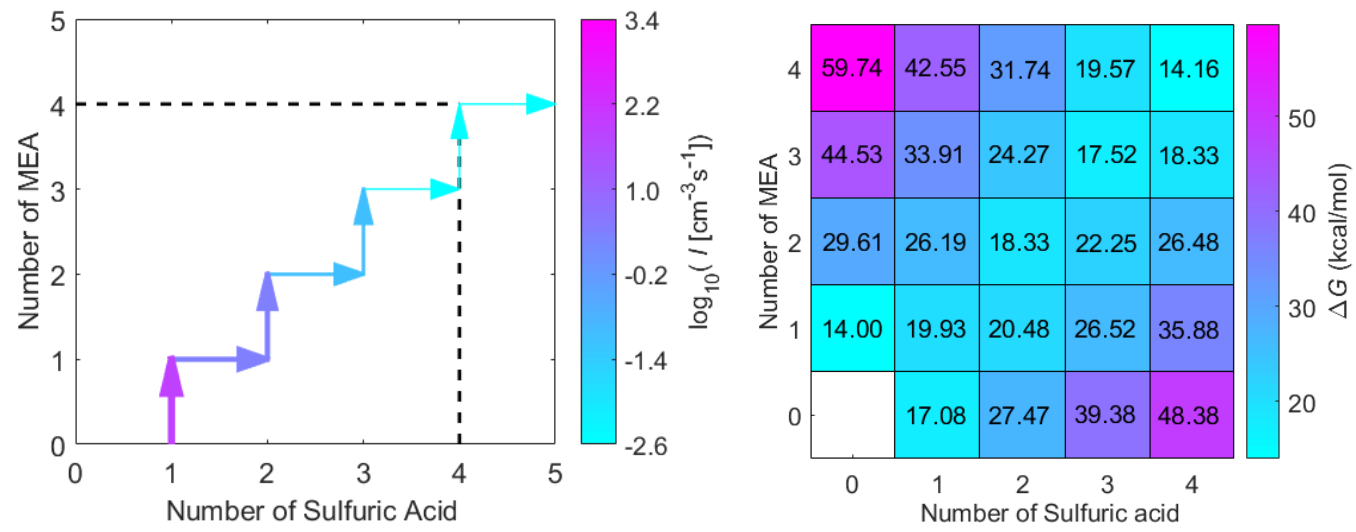

346 Figure 6. Main clustering pathways (left panel) and actual Gibbs free energy surface

347 for the formation of clusters $\mathrm{MEA}_{m}\left(\mathrm{H}_{2} \mathrm{SO}_{4}\right)_{n}(m=0-4$ and $n=0-4)$ (right panel) at 278.15

$348 \mathrm{~K},\left[\mathrm{H}_{2} \mathrm{SO}_{4}\right]=10^{6} \mathrm{~cm}^{-3}$ and $[\mathrm{MEA}]=10$ ppt. For figure clarity, the pathways 349 contributing less than $5 \%$ to the flux of the cluster are not shown.

We also compared the growth pathways for MEA- $\mathrm{H}_{2} \mathrm{SO}_{4}$ with $\mathrm{MA}-\mathrm{H}_{2} \mathrm{SO}_{4}$ and

351 DMA- $\mathrm{H}_{2} \mathrm{SO}_{4}$ system at the same simulation condition. The formation pathways for

$352 \mathrm{MA}-\mathrm{H}_{2} \mathrm{SO}_{4}$ and DMA- $\mathrm{H}_{2} \mathrm{SO}_{4}$ are presented in Figure $\mathrm{S} 6$. A common feature is that the

353 initially formed cluster mainly consists of one $\mathrm{H}_{2} \mathrm{SO}_{4}$ and one base molecule for all

354 three amines. However, as a whole, the growth pathway for the MEA- $\mathrm{H}_{2} \mathrm{SO}_{4}$ system is 355 significantly different from that of the $\mathrm{MA}-\mathrm{H}_{2} \mathrm{SO}_{4}$ and $\mathrm{DMA}-\mathrm{H}_{2} \mathrm{SO}_{4}$ systems. In 356 accordance with a previous study, ${ }^{47}$ collisions involving the (DMA) $1(\mathrm{SA})_{1}$ cluster 357 contribute significantly to the growth for DMA-SA system, which makes the growth 358 occur mainly along the diagonal on the acid-base grid. In contrast to MEA and DMA, 359 the cluster growth for the MA system does not follow the diagonal direction and the 360 formation of larger clusters $(\mathrm{MA})_{1}(\mathrm{SA})_{2}$ and $(\mathrm{MA})_{2}(\mathrm{SA})_{3}$ has two pathways either via 
addition of $\mathrm{H}_{2} \mathrm{SO}_{4}$ or MA. The sulfuric acid dimer has a significant population in the

362 initial clusters, which results from the low stability of the (MA) $1(\mathrm{SA})_{2}$ cluster.

363 Effect of Hydration. As water is many orders of magnitude more abundant than

364 sulfuric acid and bases in the atmosphere, hydration might change the cluster formation

365 free energies and therefore cluster formation kinetics ${ }^{61,65,66}$ Previous studies have found

366 that clusters consisting of $\mathrm{H}_{2} \mathrm{SO}_{4}$ and DMA or ammonia are mainly hydrated by less

367 than three $\mathrm{H}_{2} \mathrm{O}$ molecules. ${ }^{30,61}$ We expected that MEA- $\mathrm{H}_{2} \mathrm{SO}_{4}$ clusters could still be

368 hydrated by less than three $\mathrm{H}_{2} \mathrm{O}$ molecules although the structure of MEA is different

369 from DMA and ammonia. Here, $1-3 \mathrm{H}_{2} \mathrm{O}$ molecules were considered to study the effect

370 of hydration on the formation kinetics of $\mathrm{MEA}-\mathrm{H}_{2} \mathrm{SO}_{4}$ clusters. In addition, to save

371 computational resources, we only selected the smallest clusters $(\mathrm{MEA})_{m}(\mathrm{SA})_{\mathrm{n}}(m=0-$

$3722, n=0-2)$ as test system to investigate the hydration. Based on the calculated

373 equilibrium hydrate distribution of the clusters at relative humidities $(\mathrm{RH}) 20 \%, 50 \%$

374 and $100 \%$, at $278.15 \mathrm{~K}$, converted from calculated Gibbs free energies of stepwise

375 hydration at $278.15 \mathrm{~K}$ and $1 \mathrm{~atm}$, we can conclude that sulfuric acid-MEA clusters are

376 only mildly hydrated ( $0-2 \mathrm{H}_{2} \mathrm{O}$ molecules depending on $\left.\mathrm{RH}\right)$. Details for the discussion

377 on calculated Gibbs free energies of stepwise hydration, optimized structures and the

378 hydrate distribution of the clusters are presented in SI. Here, we mainly focus on the

379 effect of hydration on the cluster formation kinetics.

380 In principle, hydration can affect the cluster formation rate both through the 381 collision and evaporation rates. However, hydration was found to have little effect on 
382 the collision rate since the collision diameter, an important factor in collision rate 383 coefficients in kinetic collision theory employed in ACDC, changes very little with 384 hydration. ${ }^{61}$ Hence, only the effect of hydration on the evaporation rates and formation 385 rates will be discussed in detail. Figure 7 presents the evaporation rates (left) and 386 formation rates (right) as a function of RH at $278.15 \mathrm{~K}$ compared to dry conditions. 387 Clearly, the presence of water has various effects on the evaporation rate depending on 388 the given cluster. Water has a little effect on the evaporation rate of the $(\mathrm{SA})_{2}$ and $389(\mathrm{MEA})_{2}(\mathrm{SA})_{2}$ and almost no effect on that of the (MEA) 2 cluster. However, the 390 evaporation rate of (MEA)(SA) 2 can be increased up to 3 times by hydration, and that 391 of $(\mathrm{MEA})_{2}(\mathrm{SA})$ can be decreased by 13 times compared to the dry case. More 392 importantly, the presence of water decreases the evaporation rate of initially formed 393 (MEA)(SA) clusters, i.e. the rate-determining step for cluster growth in the system, and 394 this trend gradually increases with RH, which explains the increased cluster formation 395 rate with increasing RH (right panel in Figure 7). The formation rate can be increased 396 about 5 fold at $\mathrm{RH}=100 \%$ compared to the dry case. It should be mentioned that 397 although the absolute formation rate obtained from a small simulation box $(2 \times 2)$ is not 398 reliable, the relative formation rate presented here should cancel out any significant bias 399 introduced by the small simulation box. Generally, from these small cluster hydration 400 simulations, we can conclude that hydration can slightly influence the evaporation rate, 401 but the effect is in all cases relatively low and does not severely influence the results. 402 Although it is not expected that qualitative conclusion from current study could be 
403 changed when larger clusters and more water molecules are used, future study with 404 larger clusters and more water molecules is still deserved, to reach a more definitive 405 conclusion about the $\mathrm{RH}$ effect on $\mathrm{MEA}-\mathrm{H}_{2} \mathrm{SO}_{4}$ cluster formation kinetics.
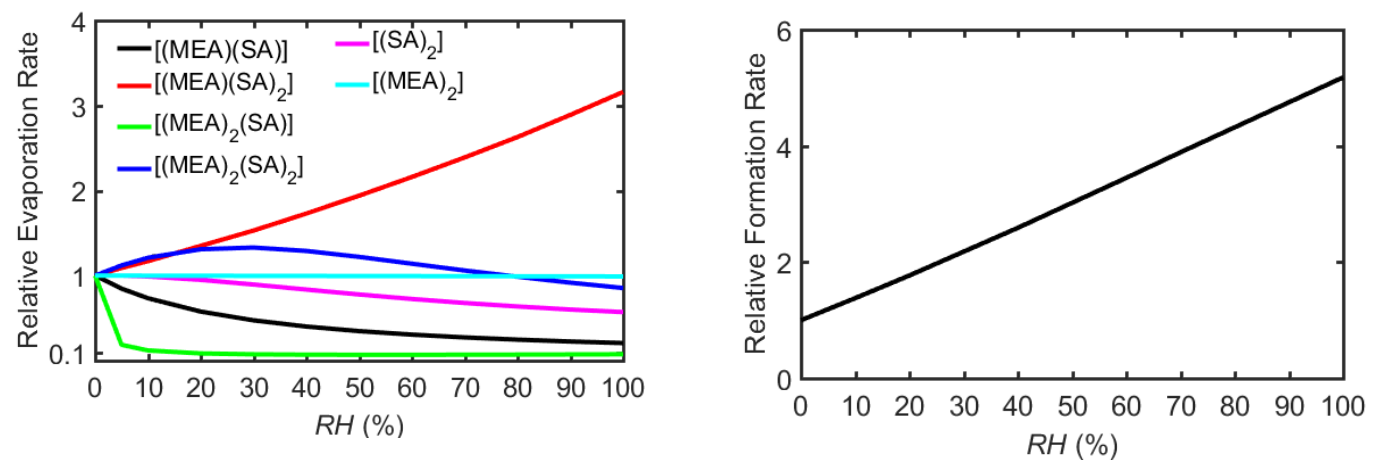

406 Figure 7. Relative evaporation rate (left panel) and cluster formation rate $\left(\left[\mathrm{H}_{2} \mathrm{SO}_{4}\right]=\right.$ $40710^{6} \mathrm{~cm}^{-3}$ and $[\mathrm{MEA}]=10 \mathrm{ppt}$ ) (right panel) as a function of relative humidity at 278.15 $408 \mathrm{~K}$.

409 Atmospheric Implications. We found that MEA at ppt-level can enhance the $\mathrm{H}_{2} \mathrm{SO}_{4}-$ 410 based NPF. The enhancing potential of MEA for NPF is lower than that of DMA, which 411 is one of the strongest agents for enhancing $\mathrm{H}_{2} \mathrm{SO}_{4}$-based NPF, ${ }^{25,43}$ and much higher 412 than that of MA. In addition, we have shown that the -OH group of MEA plays an 413 important role in enhancing $\mathrm{H}_{2} \mathrm{SO}_{4}$-based NPF due to the formation of additional $\mathrm{H}$ 414 bonds with $\mathrm{H}_{2} \mathrm{SO}_{4}$. To the best of our knowledge, this is the first study to point out the 415 significant effect of one additional functional group in amines and show that the basicity 416 of bases is not necessarily the only determining factor influencing $\mathrm{H}_{2} \mathrm{SO}_{4}$ driven NPF. 417 Besides anthropogenic emission, ${ }^{67}$ the oxidation of aliphatic amines could introduce $418 \mathrm{OH}$ or keto-, peroxy- and carboxylic acid groups in the atmosphere. ${ }^{31,68,69}$ Amines 419 including these additional H-bond donor/acceptor functional groups can enhance the 
NPF via a synergetic role of the basicity and the formation of additional H-bonds,

421 especially for strongly basic amines. As the enhancing effect is very dependent on the exact structure of the molecule, the effect of these amines on NPF deserves further investigation. MEA. It is known that the reaction with $\cdot \mathrm{OH}$ is an important sink for MEA due to a high reaction rate constant $\left(k_{\mathrm{OH}} 8.1 \times 10^{-11} \mathrm{~cm}^{-3}\right.$ molecule $\mathrm{s}^{-1}$ at $\left.278.15 \mathrm{~K}\right)$ and concentration of $\cdot \mathrm{OH}\left(9.7 \times 10^{5} \mathrm{~cm}^{-3}\right) .{ }^{18}$ At daytime, $\mathrm{H}_{2} \mathrm{SO}_{4}$ and $\cdot \mathrm{OH}$ can coexist in the atmosphere and atmospheric concentration of $\mathrm{H}_{2} \mathrm{SO}_{4}\left(1 \times 10^{6}-1.9 \times 10^{7} \mathrm{~cm}^{-3}\right.$ depending 429 on the location $)^{70-72}$ is usually $1-19$ times that of $\cdot \mathrm{OH}$. We estimated the relative contribution of $\mathrm{H}_{2} \mathrm{SO}_{4}$ to $\cdot \mathrm{OH}$ for the removal of MEA by $k \mathrm{H}_{2} \mathrm{SO}_{4}\left[\mathrm{H}_{2} \mathrm{SO}_{4}\right] / k \mathrm{OH}[\cdot \mathrm{OH}]$ at $431278.15 \mathrm{~K}$, where $k_{\mathrm{H} 2 \mathrm{SO} 4}$ is removal rate constants of MEA for the participation in NPF 432 involving $\mathrm{H}_{2} \mathrm{SO}_{4}$ and its value is estimated to be $2.16 \times 10^{-11}$ and $5.6 \times 10^{-11} \mathrm{~cm}^{3}$ molecule $433{ }^{1} \mathrm{~s}^{-1}$ at dry or $50 \% \mathrm{RH}$ condition, respectively (computational details in $\mathrm{SI}$ ), $\left[\mathrm{H}_{2} \mathrm{SO}_{4}\right]$ 434 and $[\cdot \mathrm{OH}]$ are the concentration of $\mathrm{H}_{2} \mathrm{SO}_{4}$ and $\cdot \mathrm{OH}$, respectively. The contribution of $435 \mathrm{H}_{2} \mathrm{SO}_{4}$ to the removal of MEA is calculated to be about 0.27-5.2 and 0.7-13.1 times that 436 of $\cdot \mathrm{OH}$ at dry and $50 \% \mathrm{RH}$ condition, respectively. This means that reactions with $437 \mathrm{H}_{2} \mathrm{SO}_{4}$ will compete with oxidation by $\cdot \mathrm{OH}$ in the atmosphere for the removal of MEA 438 at tropospheric condition. Especially in regions where the concentration of $\mathrm{H}_{2} \mathrm{SO}_{4}$ is 439 high, NPF might be the dominant removal process of gas-phase MEA. Therefore, the 440 participation of MEA in $\mathrm{H}_{2} \mathrm{SO}_{4}$-based NPF should be considered when assessing the 
441 environmental risk of MEA emissions related to, for example, postcombustion $\mathrm{CO}_{2}$

442 capture technology.

443 ASSOCIATED CONTENT

444 Supporting Information. Details for boundary conditions, discussion on the stability

445 of cluster, hydration free energies, removal rate constants of MEA in NPF of $\mathrm{H}_{2} \mathrm{SO}_{4}$,

446 thermochemical information for the formation of molecular clusters, evaporation

447 coefficients for all evaporation pathways of different clusters, lower energy structures

448 for $\mathrm{NH}_{3}-\mathrm{H}_{2} \mathrm{SO}_{4}$ and dimethylamine (DMA) $-\mathrm{H}_{2} \mathrm{SO}_{4}$, low energy structure involving the

449 hydrogen bonds between - $\mathrm{OH}$ of all MEA and $\mathrm{H}_{2} \mathrm{SO}_{4}$, Formation free energies for the

450 clusters for $\mathrm{MA} / \mathrm{NH}_{3}-\mathrm{H}_{2} \mathrm{SO}_{4}$, evaporation rates for $\mathrm{MA} / \mathrm{DMA}-\mathrm{H}_{2} \mathrm{SO}_{4}$ clusters, the

451 cluster formation rates and steady-state $\mathrm{H}_{2} \mathrm{SO}_{4}$ dimer concentrations as a function of

452 temperature, the main clustering pathways for $\mathrm{MA} / \mathrm{DMA}-\mathrm{H}_{2} \mathrm{SO}_{4}$ clusters, hydrate

453 distribution of clusters and coordinates of all optimized clusters. This material is

454 available free of charge via the Internet at http://pubs.acs.org.

455 AUTHOR INFORMATION

456 Corresponding Author

457 *Phone/fax: +86-411-84707844; e-mail: hbxie@dlut.edu.cn.

458 ACKNOWLEDGEMENTS

459 We thank the National Natural Science Foundation of China $(21677028,21325729)$

460 and ERC 692891-DAMOCLES. We thank the CSC-IT Center for Science in Espoo,

461 Finland, for computational resources, Jonas Elm thanks the Carlsberg Foundation for

462 financial support and Hong-Bin Xie thanks the China Scholarship Council. 
464 (1) Veawab, A.; Tontiwachwuthikul, P.; Chakma, A., Corrosion Behavior of Carbon 465 Steel in the $\mathrm{CO}_{2}$ Absorption Process Using Aqueous Amine Solutions. Ind. Eng. Chem. 466 Res. 1999, 38 (10), 3917-3924.

467 (2) Liu, Y.; Zhang, L.; Watanasiri, S., Representing Vapor-Liquid Equilibrium for an 468 Aqueous MEA-CO ${ }_{2}$ System Using the Electrolyte Nonrandom-Two-Liquid Model. 469 Ind. Eng. Chem. Res. 1999, 38 (5), 2080-2090.

470 (3) Puxty, G.; Rowland, R.; Allport, A.; Yang, Q.; Bown, M.; Burns, R.; Maeder, M.; 471 Attalla, M., Carbon Dioxide Postcombustion Capture: A Novel Screening Study of 472 the Carbon Dioxide Absorption Performance of 76 Amines. Environ. Sci. Technol. 473 2009, 43 (16), 6427-6433.

474 (4) Xie, H.-B.; He, N.; Song, Z.; Chen, J.; Li, X., Theoretical Investigation on the 475 Different Reaction Mechanisms of Aqueous 2-Amino-2-methyl-1-propanol and 476 Monoethanolamine with $\mathrm{CO}_{2}$. Ind. Eng. Chem. Res. 2014, 53, (8), 3363-3372.

477 (5) Xie, H.-B.; Johnson, J. K.; Perry, R. J.; Genovese, S.; Wood, B. R., A Computational 478 Study of the Heats of Reaction of Substituted Monoethanolamine with $\mathrm{CO}_{2}$. J. Phys. 479 Chem. A 2011, 115 (3), 342-350.

480 (6) Xie, H.-B.; Li, C.; He, N.; Wang, C.; Zhang, S.; Chen, J., Atmospheric Chemical 481 Reactions of Monoethanolamine Initiated by $\mathrm{OH}$ Radical: Mechanistic and Kinetic 482 Study. Environ. Sci. Technol. 2014, 48 (3), 1700-1706.

483 (7) Xie, H.-B.; Wei, X.; Wang, P.; He, N.; Chen, J., $\mathrm{CO}_{2}$ Absorption in an Alcoholic 484 Solution of Heavily Hindered Alkanolamine: The Reaction Mechanism of 2-(tert485 butylamino)- ethanol with $\mathrm{CO}_{2}$ Revisited. J. Phys. Chem. A 2015, 119, 6346-6353

486 (8) Xie, H.-B.; Zhou, Y.; Zhang, Y.; Johnson, J. K., Reaction Mechanism of 487 Monoethanolamine with $\mathrm{CO}_{2}$ in Aqueous Solution from Molecular Modeling. J. Phys. 488 Chem. A 2010, 114, (43), 11844-11852.

489 (9) da Silva, E. F.; Booth, A. M., Emissions from Postcombustion $\mathrm{CO}_{2}$ Capture Plants. 490 Environ. Sci. Technol. 2013, 47 (2), 659-660.

491 (10) Kapteina, S.; Slowik, K.; Verevkin, S. P.; Heintz, A., Vapor Pressures and 492 Vaporization Enthalpies of a Series of Ethanolamines. J. Chem. Eng. Data 2005, 50 (2), 493 398-402.

494 (11) Karl, M.; Wright, R. F.; Berglen, T. F.; Denby, B., Worst Case Scenario Study to 495 Assess the Environmental Impact of Amine Emissions from a $\mathrm{CO}_{2}$ Capture Plant. Int. 496 J. Greenhouse Gas Control 2011, 5 (3), 439-447.

497 (12) Veltman, K.; Singh, B.; Hertwich, E. G., Human and Environmental Impact 498 Assessment of Postcombustion $\mathrm{CO}_{2}$ Capture Focusing on Emissions from Amine499 Based Scrubbing Solvents to Air. Environ. Sci. Technol. 2010, 44 (4), 1496-1502.

500 (13) Xie, H.-B.; Ma, F.; Wang, Y.; He, N.; Yu, Q.; Chen, J., Quantum Chemical Study 501 on Cl-Initiated Atmospheric Degradation of Monoethanolamine. Environ. Sci. 502 Technol. 2015, 49 (22), 13246-13255.

503 (14) Karl, M.; Dye, C.; Schmidbauer, N.; Wisthaler, A.; Mikoviny, T.; D'Anna, B.; 504 Müller, M.; Borrás, E.; Clemente, E.; Muñoz, A.; Porras, R.; Ródenas, M.; Vázquez, 
M.; Brauers, T., Study of OH-initiated Degradation of 2-aminoethanol. Atmos. Chem. Phys. 2012, 12 (4), 1881-1901.

(15) Karl, M.; Svendby, T.; Walker, S. E.; Velken, A. S.; Castell, N.; Solberg, S., Modelling atmospheric oxidation of 2-aminoethanol (MEA) emitted from postcombustion capture using WRF-Chem. Sci. Total Environ. 2015, 527-528, 185-202. (16) Nielsen, C. J.; D’Anna, B.; Dye, C.; Graus, M.; Karl, M.; King, S.; Maguto, M. M.; Müller, M.; Schmidbauer, N.; Stenstrøm, Y.; Wisthaler, A.; Pedersen, S., Atmospheric chemistry of 2-aminoethanol (MEA). Energy Proc. 2011, 4, 2245-2252. (17) Nielsen, C. J.; Herrmann, H.; Weller, C., Atmospheric Chemistry and Environmental Impact of the Use of Amines in Carbon Capture and Storage (CCS). Chem. Soc. Rev. 2012, 41 (19), 6684-6704.

(18) Onel, L.; Blitz, M. A.; Seakins, P. W., Direct Determination of the Rate Coefficient for the Reaction of OH Radicals with Monoethanol Amine (MEA) from 296 to $510 \mathrm{~K}$. J. Phys. Chem.Lett. 2012, 3 (7), 853-856.

(19) Borduas, N.; Abbatt, J. P. D.; Murphy, J. G., Gas Phase Oxidation of Monoethanolamine (MEA) with $\mathrm{OH}$ Radical and Ozone: Kinetics, Products, and Particles. Environ. Sci. Technol. 2013, 47 (12), 6377-6383.

(20) da Silva, G., Atmospheric Chemistry of 2-Aminoethanol (MEA): Reaction of the $\mathrm{NH}_{2} \cdot \mathrm{CHCH}_{2} \mathrm{OH}$ Radical with O . J. Phys. Chem. A 2012, 116 (45), 10980-10986.

(21) Manzoor, S.; Simperler, A.; Korre, A., A Theoretical Study of the Reaction Kinetics of Amines Released into the Atmosphere from $\mathrm{CO}_{2}$ Capture. Int. J. Greenhouse Gas Control 2015, 41, 219-228.

(22) Onel, L.; Blitz, M. A.; Breen, J.; Rickard, A. R.; Seakins, P. W., Branching Ratios for the Reactions of $\mathrm{OH}$ with Ethanol Amines Used in Carbon Capture and the Potential Impact on Carcinogen Formation in the Emission Plume from a Carbon Capture Plant. Phys. Chem. Chem.Phys. 2015, 17 (38), 25342-25353.

(23) Zhang, R.; Suh, I.; Zhao, J.; Zhang, D.; Fortner, E. C.; Tie, X.; Molina, L. T.; Molina, M. J., Atmospheric New Particle Formation Enhanced by Organic Acids. Science 2004, 304 (5676), 1487-1490.

(24) Winkler, P. M.; Steiner, G.; Vrtala, A.; Vehkamäki, H.; Noppel, M.; Lehtinen, K. E. J.; Reischl, G. P.; Wagner, P. E.; Kulmala, M., Heterogeneous Nucleation Experiments Bridging the Scale from Molecular Ion Clusters to Nanoparticles. Science 2008, 319, (5868), 1374-1377.

(25) Almeida, J.; Schobesberger, S.; Kurten, A.; Ortega, I. K.; Kupiainen-Maatta, O.; Praplan, A. P.; Adamov, A.; Amorim, A.; Bianchi, F.; Breitenlechner, M.; David, A.; Dommen, J.; Donahue, N. M.; Downard, A.; Dunne, E.; Duplissy, J.; Ehrhart, S.; Flagan, R. C.; Franchin, A.; Guida, R.; Hakala, J.; Hansel, A.; Heinritzi, M.; Henschel, H.; Jokinen, T.; Junninen, H.; Kajos, M.; Kangasluoma, J.; Keskinen, H.; Kupc, A.; Kurten, T.; Kvashin, A. N.; Laaksonen, A.; Lehtipalo, K.; Leiminger, M.; Leppa, J.; Loukonen, V.; Makhmutov, V.; Mathot, S.; McGrath, M. J.; Nieminen, T.; Olenius, T.; Onnela, A.; Petaja, T.; Riccobono, F.; Riipinen, I.; Rissanen, M.; Rondo, L.; Ruuskanen, T.; Santos, F. D.; Sarnela, N.; Schallhart, S.; Schnitzhofer, R.; Seinfeld, J. 
H.; Simon, M.; Sipila, M.; Stozhkov, Y.; Stratmann, F.; Tome, A.; Trostl, J.; Tsagkogeorgas, G.; Vaattovaara, P.; Viisanen, Y.; Virtanen, A.; Vrtala, A.; Wagner, P. E.; Weingartner, E.; Wex, H.; Williamson, C.; Wimmer, D.; Ye, P.; Yli-Juuti, T.; Carslaw, K. S.; Kulmala, M.; Curtius, J.; Baltensperger, U.; Worsnop, D. R.; Vehkamaki, H.; Kirkby, J., Molecular Understanding of Sulphuric Scid-amine Particle Nucleation in the Atmosphere. Nature 2013, 502 (7471), 359-363.

(26) Ehn, M.; Thornton, J. A.; Kleist, E.; Sipila, M.; Junninen, H.; Pullinen, I.; Springer, M.; Rubach, F.; Tillmann, R.; Lee, B.; Lopez-Hilfiker, F.; Andres, S.; Acir, I.-H.; Rissanen, M.; Jokinen, T.; Schobesberger, S.; Kangasluoma, J.; Kontkanen, J.; Nieminen, T.; Kurten, T.; Nielsen, L. B.; Jorgensen, S.; Kjaergaard, H. G.; Canagaratna, M.; Maso, M. D.; Berndt, T.; Petaja, T.; Wahner, A.; Kerminen, V.-M.; Kulmala, M.; Worsnop, D. R.; Wildt, J.; Mentel, T. F., A Large Source of Low-volatility Secondary Organic Aerosol. Nature 2014, 506, (7489), 476-479.

(27) Wang, Y. H.; Liu, Z. R.; Zhang, J. K.; Hu, B.; Ji, D. S.; Yu, Y. C.; Wang, Y. S., Aerosol Physicochemical Properties and Implications for Visibility During an Intense Haze Episode During Winter in Beijing. Atmos. Chem. Phys. 2015, 15, (6), 3205-3215. (28) Kirkby, J.; Curtius, J.; Almeida, J.; Dunne, E.; Duplissy, J.; Ehrhart, S.; Franchin, A.; Gagne, S.; Ickes, L.; Kurten, A.; Kupc, A.; Metzger, A.; Riccobono, F.; Rondo, L.; Schobesberger, S.; Tsagkogeorgas, G.; Wimmer, D.; Amorim, A.; Bianchi, F.; Breitenlechner, M.; David, A.; Dommen, J.; Downard, A.; Ehn, M.; Flagan, R. C.; Haider, S.; Hansel, A.; Hauser, D.; Jud, W.; Junninen, H.; Kreissl, F.; Kvashin, A.; Laaksonen, A.; Lehtipalo, K.; Lima, J.; Lovejoy, E. R.; Makhmutov, V.; Mathot, S.; Mikkila, J.; Minginette, P.; Mogo, S.; Nieminen, T.; Onnela, A.; Pereira, P.; Petaja, T.; Schnitzhofer, R.; Seinfeld, J. H.; Sipila, M.; Stozhkov, Y.; Stratmann, F.; Tome, A.; Vanhanen, J.; Viisanen, Y.; Vrtala, A.; Wagner, P. E.; Walther, H.; Weingartner, E.; Wex, H.; Winkler, P. M.; Carslaw, K. S.; Worsnop, D. R.; Baltensperger, U.; Kulmala, M., Role of Sulphuric Acid, Ammonia and Galactic Cosmic Rays in Atmospheric Aerosol Nucleation. Nature 2011, 476 (7361), 429-433.

(29) Kurtén, T.; Loukonen, V.; Vehkamäki, H.; Kulmala, M., Amines Are Likely to Enhance Neutral and Ion-induced Sulfuric Acid-water Nucleation in the Atmosphere more Effectively than Ammonia. Atmos. Chem. Phys. 2008, 8 (14), 4095-4103. (30) Loukonen, V.; Kurtén, T.; Ortega, I. K.; Vehkamäki, H.; Pádua, A. A. H.; Sellegri, K.; Kulmala, M., Enhancing Effect of Dimethylamine in Sulfuric Acid Nucleation in the Presence of Water - a Computational Study. Atmos. Chem. Phys. 2010, 10 (10), 4961-4974.

(31) Murphy, S. M.; Sorooshian, A.; Kroll, J. H.; Ng, N. L.; Chhabra, P.; Tong, C.; Surratt, J. D.; Knipping, E.; Flagan, R. C.; Seinfeld, J. H., Secondary Aerosol Formation from Atmospheric Reactions of Aliphatic Amines. Atmos. Chem. Phys. 2007, 7 (9), 2313-2337.

(32) Berndt, T.; Stratmann, F.; Sipilä, M.; Vanhanen, J.; Petäjä, T.; Mikkilä, J.; Grüner, A.; Spindler, G.; Lee Mauldin Iii, R.; Curtius, J.; Kulmala, M.; Heintzenberg, J., Laboratory Study on New Particle Formation from the Reaction $\mathrm{OH}+\mathrm{SO}_{2}$ : Influence 
of Experimental Conditions, $\mathrm{H}_{2} \mathrm{O}$ Vapour, $\mathrm{NH}_{3}$ and the Amine Tert-butylamine on the Overall Process. Atmos. Chem. Phys. 2010, 10 (15), 7101-7116.

(33) Smith, J. N.; Barsanti, K. C.; Friedli, H. R.; Ehn, M.; Kulmala, M.; Collins, D. R.; Scheckman, J. H.; Williams, B. J.; McMurry, P. H., Observations of Aminium Salts in Atmospheric Nanoparticles and Possible Climatic Implications. Proc. Natl. Acad. Sci. 2010, 107 (15), 6634-6639.

(34) Zhao, J.; Smith, J. N.; Eisele, F. L.; Chen, M.; Kuang, C.; McMurry, P. H., Observation of Neutral Sulfuric Acid-amine Containing Clusters in Laboratory and Ambient Measurements. Atmos. Chem. Phys. 2011, 11 (21), 10823-10836.

(35) Erupe, M. E.; Viggiano, A. A.; Lee, S. H., The Effect of Trimethylamine on Atmospheric Nucleation Involving $\mathrm{H}_{2} \mathrm{SO}_{4}$. Atmos. Chem. Phys. 2011, 11 (10), 47674775.

(36) Lehtipalo, K.; Rondo, L.; Kontkanen, J.; Schobesberger, S.; Jokinen, T.; Sarnela, N.; Kürten, A.; Ehrhart, S.; Franchin, A.; Nieminen, T.; Riccobono, F.; Sipilä, M.; YliJuuti, T.; Duplissy, J.; Adamov, A.; Ahlm, L.; Almeida, J.; Amorim, A.; Bianchi, F.; Breitenlechner, M.; Dommen, J.; Downard, A. J.; Dunne, E. M.; Flagan, R. C.; Guida, R.; Hakala, J.; Hansel, A.; Jud, W.; Kangasluoma, J.; Kerminen, V.-M.; Keskinen, H.; Kim, J.; Kirkby, J.; Kupc, A.; Kupiainen-Määttä, O.; Laaksonen, A.; Lawler, M. J.; Leiminger, M.; Mathot, S.; Olenius, T.; Ortega, I. K.; Onnela, A.; Petäjä, T.; Praplan, A.; Rissanen, M. P.; Ruuskanen, T.; Santos, F. D.; Schallhart, S.; Schnitzhofer, R.; Simon, M.; Smith, J. N.; Tröstl, J.; Tsagkogeorgas, G.; Tomé, A.; Vaattovaara, P.; Vehkamäki, H.; Vrtala, A. E.; Wagner, P. E.; Williamson, C.; Wimmer, D.; Winkler, P. M.; Virtanen, A.; Donahue, N. M.; Carslaw, K. S.; Baltensperger, U.; Riipinen, I.; Curtius, J.; Worsnop, D. R.; Kulmala, M., The Effect of Acid-base Clustering and Ions on the Growth of Atmospheric Nano-particles. Nat. Commun. 2016, 7, 11594.

(37) Chen, M.; Titcombe, M.; Jiang, J.; Jen, C.; Kuang, C.; Fischer, M. L.; Eisele, F. L.; Siepmann, J. I.; Hanson, D. R.; Zhao, J.; McMurry, P. H., Acid-base Chemical Reaction Model for Nucleation Rates in the Polluted Atmospheric Boundary Layer. Proc. Natl. Acad. Sci. 2012, 109 (46), 18713-18718.

(38) Xu, Z.-Z.; Fan, H.-J., Competition Between $\mathrm{H}_{2} \mathrm{SO}_{4}-\left(\mathrm{CH}_{3}\right)_{3} \mathrm{~N}$ and $\mathrm{H}_{2} \mathrm{SO}_{4}-\mathrm{H}_{2} \mathrm{O}$ Interactions: Theoretical Studies on the Clusters $\left[\left(\mathrm{CH}_{3}\right)_{3} \mathrm{~N}\right] \cdot\left(\mathrm{H}_{2} \mathrm{SO}_{4}\right) \cdot\left(\mathrm{H}_{2} \mathrm{O}\right)_{3-7}$. J. Phy. Chem. A 2015, 119 (34), 9160-9166.

(39) Lv, S.-S.; Miao, S.-K.; Ma, Y.; Zhang, M.-M.; Wen, Y.; Wang, C.-Y.; Zhu, Y.-P.; Huang, W., Properties and Atmospheric Implication of Methylamine-Sulfuric AcidWater Clusters. J. Phy. Chem. A 2015, 119 (32), 8657-8666.

(40) Nadykto, A.; Yu, F.; Jakovleva, M.; Herb, J.; Xu, Y., Amines in the Earth's Atmosphere: A Density Functional Theory Study of the Thermochemistry of PreNucleation Clusters. Entropy 2011, 13 (2), 554-569.

(41) Nadykto, A.; Herb, J.; Yu, F.; Xu, Y.; Nazarenko, E., Estimating the Lower Limit of the Impact of Amines on Nucleation in the Earth's Atmosphere. Entropy 2015, 17(5), 2764-2780. 
(42) Nadykto, A. B.; Herb, J.; Yu, F.; Xu, Y., Enhancement in the Production of

631 Nucleating Clusters due to Dimethylamine and Large Uncertainties in the 632 Thermochemistry of Amine-enhanced Nucleation. Chem. Phys. Lett. 2014, 609, 42-49.

633 (43) Jen, C. N.; McMurry, P. H.; Hanson, D. R., Stabilization of Sulfuric Acid Dimers 634 by Ammonia, Methylamine, Dimethylamine, and Trimethylamine. J. Geophys. Res. 635 Atmos. 2014, 119 (12), 7502-7514.

636 (44) Jen, C. N.; Bachman, R.; Zhao, J.; McMurry, P. H.; Hanson, D. R., Diamine637 sulfuric Acid Reactions Are a Potent Source of New Particle Formation. Geophys. Res. 638 Lett. 2016, 43 (2), 867-873.

639 (45) Elm, J.; Jen, C. N.; Kurtén, T.; Vehkamäki, H., Strong Hydrogen Bonded 640 Molecular Interactions between Atmospheric Diamines and Sulfuric Acid. J. Phy. 641 Chem. A 2016, 120 (20), 3693-3700.

642 (46) Hall, H. K., Correlation of the Base Strengths of Amines1. J. Am. Chem. Soc. 1957, $64379(20), 5441-5444$.

644 (47) McGrath, M. J.; Olenius, T.; Ortega, I. K.; Loukonen, V.; Paasonen, P.; Kurtén, 645 T.; Kulmala, M.; Vehkamäki, H., Atmospheric Cluster Dynamics Code: a flexible 646 method for solution of the birth-death equations. Atmos. Chem. Phys. 2012, 12 (5), $647 \quad 2345-2355$.

648 (48) Olenius T, K.-M. O. I., Kurtén T, Vehkamäki H., Free Energy Barrier in the 649 Growth of Sulfuric Acid-ammonia and Sulfuric Acid-dimethylamine Clusters. $J$. 650 Chem. Phys. 2013, 139 (8), 084312.

651 (49) Ortega, I. K.; Kupiainen, O.; Kurtén, T.; Olenius, T.; Wilkman, O.; McGrath, M. 652 J.; Loukonen, V.; Vehkamäki, H., From Quantum Chemical Formation Free Energies 653 to Evaporation Rates. Atmos. Chem. Phys. 2012, 12 (1), 225-235.

654 (50) Elm, J.; Fard, M.; Bilde, M.; Mikkelsen, K. V., Interaction of Glycine with 655 Common Atmospheric Nucleation Precursors. J. Phy. Chem. A 2013, 117 (48), 1299065612997.

657 (51) Elm, J.; Myllys, N.; Hyttinen, N.; Kurtén, T., Computational Study of the 658 Clustering of a Cyclohexene Autoxidation Product $\mathrm{C}_{6} \mathrm{H}_{8} \mathrm{O}_{7}$ with Itself and Sulfuric 659 Acid. J. Phy. Chem. A 2015, 119 (30), 8414-8421.

660 (52) Frisch, M. J.; Trucks, G. W.; H.B, S.; Scuseria, G. E.; Robb, M. A.; Cheeseman, 661 J. R., et.al Gaussian 09, 2009

662 (53) Elm, J.; Bilde, M.; Mikkelsen, K. V., Assessment of Binding Energies of 663 Atmospherically Relevant Clusters. Phys. Chem. Chem. Phys. 2013, 15 (39), 1644266416445.

665 (54) Elm, J.; Kristensen, K., Basis Set Convergence of the Binding Eenergies of 666 Strongly Hydrogen-bonded Atmospheric Clusters. Phys. Chem. Chem. Phys. 2017, 19 667 (2), 1122-1133.

668 (55) Riplinger, C.; Neese, F., An Efficient and Near Linear Scaling Pair Natural Orbital 669 Based Local Coupled Cluster Method. J. Chem. Phys. 2013, 138 (3), 034106. 
(56) Riplinger, C.; Sandhoefer, B.; Hansen, A.; Neese, F., Natural Triple Excitations in Local Coupled Cluster Calculations with Pair Natural Orbitals. J. Chem. Phys. 2013, 139 (13), 134101.

(57) Neese, F., The ORCA program system. Wiley Interdiscip. Rev. Comput. Mol. Sci. 2012, 2 (1), 73-78.

(58) Myllys, N.; Elm, J.; Halonen, R.; Kurtén, T.; Vehkamäki, H., Coupled Cluster Evaluation of the Stability of Atmospheric Acid-Base Clusters with up to 10 Molecules. J. Phy. Chem. A 2016, 120 (4), 621-630.

(59) Vorobyov, I.; Yappert, M. C.; DuPré, D. B., Hydrogen Bonding in Monomers and Dimers of 2-Aminoethanol. J. Phy. Chem. A 2002, 106 (4), 668-679.

(60) Tinja Olenius, Roope Halonen, Theo Kurtén, Henning Henschel, Oona KupiainenMäättä, Ismael K. Ortega, Hanna Vehkamäki, and Ilona Riipinen, New Particle Formation from Sulfuric Acid and Amines: Comparison of Mono-, Di-, and Trimethylamines. Submitted to Journal of Geophysical Research: Atmospheres.

(61) Henschel, H.; Kurtén, T.; Vehkamäki, H., Computational Study on the Effect of Hydration on New Particle Formation in the Sulfuric Acid/Ammonia and Sulfuric Acid/Dimethylamine Systems. J. Phy. Chem. A 2016, 120 (11), 1886-1896.

(62) Kerminen, V. M.; Petäjä, T.; Manninen, H. E.; Paasonen, P.; Nieminen, T.; Sipilä, M.; Junninen, H.; Ehn, M.; Gagné, S.; Laakso, L.; Riipinen, I.; Vehkamäki, H.; Kurten, T.; Ortega, I. K.; Dal Maso, M.; Brus, D.; Hyvärinen, A.; Lihavainen, H.; Leppä, J.; Lehtinen, K. E. J.; Mirme, A.; Mirme, S.; Hõrrak, U.; Berndt, T.; Stratmann, F.; Birmili, W.; Wiedensohler, A.; Metzger, A.; Dommen, J.; Baltensperger, U.; Kiendler-Scharr, A.; Mentel, T. F.; Wildt, J.; Winkler, P. M.; Wagner, P. E.; Petzold, A.; Minikin, A.; Plass-Dülmer, C.; Pöschl, U.; Laaksonen, A.; Kulmala, M., Atmospheric Nucleation: Highlights of the EUCAARI Project and Future Directions. Atmos. Chem. Phys. 2010, 10 (22), 10829-10848.

Chen, H.; Varner, M. E.; Gerber, R. B.; Finlayson-Pitts, B. J., Reactions of Methanesulfonic Acid with Amines and Ammonia as a Source of New Particles in Air. J. Phys.Chem. B 2016, 120(8), 1526-1536.

(64) Ling, J.; Ding, X.; Li, Z.; Yang, J., First-Principles Study of Molecular Clusters Formed by Nitric Acid and Ammonia. J. Phy. Chem. A 2017, 121 (3), 661-668.

(65) DePalma, J. W.; Wang, J.; Wexler, A. S.; Johnston, M. V., Growth of Ammonium Bisulfate Clusters by Adsorption of Oxygenated Organic Molecules. J. Phy. Chem. A 2015, 119 (45), 11191-11198.

(66) DePalma, J. W.; Doren, D. J.; Johnston, M. V., Formation and Growth of Molecular Clusters Containing Sulfuric Acid, Water, Ammonia, and Dimethylamine. J. Phy. Chem. A 2014, 118 (29), 5464-5473.

(67) Ge, X.; Wexler, A. S.; Clegg, S. L., Atmospheric Amines - Part I. A review. Atmos. Environ. 2011, 45 (3), 524-546.

(68) Price, D. J.; Clark, C. H.; Tang, X.; Cocker, D. R.; Purvis-Roberts, K. L.; Silva, P. J., Proposed Chemical Mechanisms leading to Secondary Organic Aerosol in the 
711 Reactions of Aliphatic Amines with Hydroxyl and Nitrate Radicals. Atmos. Environ. 712 2014, 96, 135-144.

713 (69) Angelino, S.; Suess, D. T.; Prather, K. A., Formation of Aerosol Particles from 714 Reactions of Secondary and Tertiary Alkylamines: Characterization by Aerosol Time715 of-Flight Mass Spectrometry. Environ. Sci. Technol. 2001, 35 (15), 3130-3138.

716 (70) Zheng, J.; Hu, M.; Zhang, R.; Yue, D.; Wang, Z.; Guo, S.; Li, X.; Bohn, B.; Shao, 717 M.; He, L.; Huang, X.; Wiedensohler, A.; Zhu, T., Measurements of Gaseous $\mathrm{H}_{2} \mathrm{SO}_{4}$ 718 by AP-ID-CIMS During CAREBeijing 2008 Campaign. Atmos. Chem. Phys. 2011, 11 719 (15), 7755-7765.

720 (71) Berresheim, H.; Elste, T.; Tremmel, H. G.; Allen, A. G.; Hansson, H. C.; Rosman, 721 K.; Dal Maso, M.; Mäkelä, J. M.; Kulmala, M.; O'Dowd, C. D., Gas-aerosol 722 relationships of $\mathrm{H}_{2} \mathrm{SO}_{4}, \mathrm{MSA}$, and $\mathrm{OH}$ : Observations in the Coastal Marine Boundary 723 Layer at Mace Head, Ireland. J. Geophys. Res. Atmos. 2002, 107 (D19), PAR 5-1-PAR 724 5-12.

725 (72) Jokinen, T.; Sipilä, M.; Junninen, H.; Ehn, M.; Lönn, G.; Hakala, J.; Petäjä, T.; 726 Mauldin Iii, R. L.; Kulmala, M.; Worsnop, D. R., Atmospheric Sulphuric Acid and 727 Neutral Cluster Mmeasurements Using CI-APi-TOF. Atmos. Chem. Phys. 2012, 12, (9), 728 4117-4125. 